\title{
1853: How Pope Pius IX Stimulated Pillarization in the Netherlands
}

\section{By Hans Knippenberg}

To cite this article: Knippenberg, H. (2021). 1853: How Pope Pius IX Stimulated Pillarization in the Netherlands. Historical Life Course Studies, 10, 162-166. https://doi.org/10.51964/hlcs9587

\section{HISTORICAL LIFE COURSE STUDIES}

Not Like Everybody Else.

Essays in Honor of Kees Mandemakers

VOLUME 10, SPECIAL ISSUE 3

2021

GUEST EDITORS

Hilde Bras

Jan Kok

Richard L. Zijdeman 


\section{HISTORICAL LIFE COURSE STUDIES}

Historical Life Course Studies is the electronic journal of the European Historical Population Samples Network (EHPSNet). The journal is the primary publishing outlet for research involved in the conversion of existing European and nonEuropean large historical demographic databases into a common format, the Intermediate Data Structure, and for studies based on these databases. The journal publishes both methodological and substantive research articles.

\section{Methodological Articles}

This section includes methodological articles that describe all forms of data handling involving large historical databases, including extensive descriptions of new or existing databases, syntax, algorithms and extraction programs. Authors are encouraged to share their syntaxes, applications and other forms of software presented in their article, if pertinent, on the openjournals website.

\section{Research articles}

This section includes substantive articles reporting the results of comparative longitudinal studies that are demographic and historical in nature, and that are based on micro-data from large historical databases.

Historical Life Course Studies is a no-fee double-blind, peer-reviewed open-access journal supported by the European Science Foundation (ESF, http://www.esf.org), the Scientific Research Network of Historical Demography (FWO Flanders, http://www.historicaldemography.be) and the International Institute of Social History Amsterdam (IISH, http://socialhistory.org/). Manuscripts are reviewed by the editors, members of the editorial and scientific boards, and by external reviewers. All journal content is freely available on the internet at https://openjournals.nl/index.php/hlcs.

\section{Co-Editors-In-Chief:}

Paul Puschmann (Radboud University) \& Luciana Quaranta (Lund University)

hislives@kuleuven.be

The European Science Foundation (ESF) provides a platform for its Member Organisations to advance science and explore new directions for research at the European level. Established in 1974 as an independent non-governmental organisation, the ESF currently serves 78 Member Organisations across 30 countries. EHPS-Net is an ESF Research Networking Programme.

The European Historical Population Samples Network (EHPS-net) brings together scholars to create a common format for databases containing non-aggregated information on persons, families and households. The aim is to form an integrated and joint interface between many European and non-European databases to stimulate comparative research on the micro-level.

Visit: http://www.ehps-net.eu.
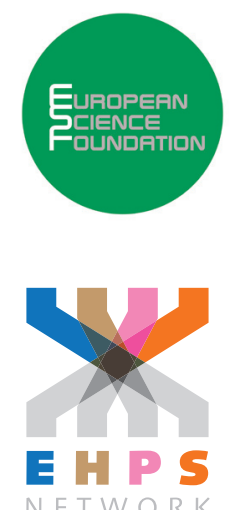


\title{
1853: How Pope Piux IX Stimulated Pillarization in the Netherlands
}

\author{
Hans Knippenberg \\ University of Amsterdam
}

\section{ABSTRACT}

In 1853 an important step in the development of the Roman Catholic Church in the Netherlands was set. On initiative of the Vatican and despite vehement resistance of the orthodox Protestant part of the population (known as the April-movement), the episcopal hierarchy in the church was restored. By choosing Utrecht in the heart of the protestant Netherlands and not Den Bosch in the Catholic South of the country as the seat of the new archbishop, the Vatican practised an offensive, national strategy. Unintendedly, the Papal choice for Utrecht contributed to the later on development of the non-territorial, personalistic solution for the Dutch multicultural society at that time: the verzuiling.

Keywords: Roman Catholic church, The Netherlands, Pillarization, Territorialisation, 19th Century, Pius IX, Utrecht, Multi-cultural society

e-ISSN: $\quad 2352-6343$

DOI article: $\quad$ https://doi.org/10.51964/hlcs9587

The article can be downloaded from here.

This open-access work is licensed under a Creative Commons Attribution 4.0 International License, which permits use, reproduction \& distribution in any medium for non-commercial purposes, provided the original author(s) and source are given credit. See http://creativecommons.org/licenses/. 


\section{MULTICULTURAL SOCIETY}

The Netherlands has a long and rich tradition as a multi-cultural society. During the 19th and the beginning of the 20th century, its religious diversity became gradually more dominant. The result was called verzuiling ('pillarization'): the segmentation of Dutch society in (orthodox) Protestants, Roman Catholics and to a lesser extent Socialists and Liberals. In many ways (orthodox) Protestants and Roman Catholics started to behave as ethnic groups (Knippenberg, 1999). Social boundaries became stronger (religiously mixed marriages diminished), religious identity was strengthened by more focus on internally created standards and values backed up by strict social control and a consequently high fertility. The two subcultures were transmitted to the following generation by denominational education. The overall foundational principle was: each pillar its own autonomy. The government was allowed to pay according to general rules (for schools, healthcare, affordable houses, etc.), but the spending remained in the hands of the pillar-organisations. The contacts between the pillars occurred at the national level, where the pillar elites concluded compromises in coalition cabinets and created political stability (Lijphart, 1975).

In this way, the Netherlands had found their own 'consociational' solution for its religious heterogeneity. It would remain operational until the 1960s only interrupted by the German occupation of 1940-1945. A territorial solution also would have been possible, since the Catholics were strongly concentrated in the southern provinces of North-Brabant and Limburg (see Map 1), that had a tradition as deviant political units (Generaliteitslanden) during the Dutch Republic (1648-1795). The well-known protestant political leader Groen van Prinsterer pleaded for that solution already in 1840: 'Men geve aan NoordBrabant en Limburg, in ons en in hun belang, een afzonderlijk bestuur' (cited in de Valk, 2002, p. 63). ${ }^{1}$ Roman Catholics living in the other provinces should preferably migrate to these provinces as well. Even in 1870 Groen regretted that this had not happened.

One of the decisions that - unintentionally - has contributed to the finally installed non-territorial verzuilings regime, was the restoration of the episcopal hierarchy in the Roman Catholic Church in 1853. The aim of this paper is to explain why.

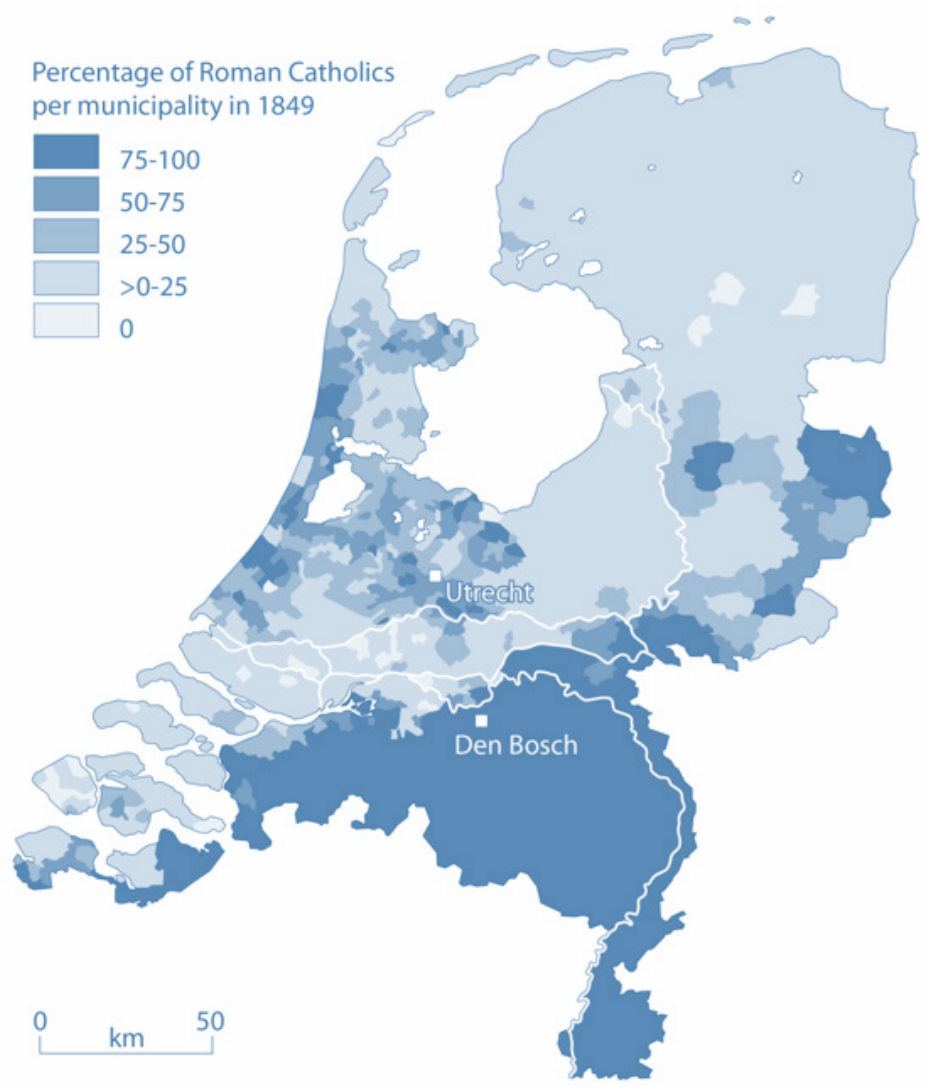

Noord-Brabant and Limburg should be provided with their own administration in our and their interest. 
The restoration of the episcopal hierarchy ended the status of missionary territory (Hollandse Zending), which a large part of the Netherlands had within the Catholic Church since 1727. Pope Pius IX erected the former apostolic vicariates Den Bosch, Breda and Roermond into dioceses and in the rest of the country two new dioceses were created: the archdiocese of Utrecht and the diocese of Haarlem. This restoration was a direct consequence of Thorbecke's liberal Constitution of 1848, that included a stronger separation between Church and State, through which churches no longer needed government approval of their organisation.

The importance of this restoration for the Catholics in the Netherlands can hardly be overestimated. It symbolised the beginning of what historian Rogier (1956) described as Catholic revival (herleving). During the Dutch Republic and together with Jews and non-Calvinist Protestants (such as Lutherans and Mennonites) Catholics were a kind of second-class citizens deprived of positions in administration, public service and education. It is true that all these groups enjoyed freedom of religion (which was rather unique in those days), but at the same time they were very restricted in practising their religion in public, resulting in many semi-clandestine churches and other places for worshiping.

Although the Batavian Revolution of 1795 ended that formal subordination, during the Kingdom of the Netherlands (from 1815) the central government initially still had an important say in religious affairs. Two separate government departments - one of Roman Catholic services and one of Reformed and other religious services - were in charge. The 1848 Constitution ended that strong interference in religious affairs and paved the way for a new relationship with the church of Rome. In the words of Kossmann (1976, p. 200): 'Not until 1853 the centuries-old idea that the Netherlands were a Protestant nation in which Catholics were a generously tolerated minority came to an end'. Nowadays, we would say that at last the Netherlands recognised itself as a multi-cultural society. And just as nowadays, also in 1853 this was not an easy task.

\title{
REACTION
}

Many Protestants had difficulties with the emancipation of their Catholic co-patriots (Knippenberg, 1992, 165-169; Vis \& Janse, 2002). Moreover they were provoked by the way the Papal breve Ex qua die, that announced the restoration, was worded. The Netherlands was slovenly described as 'Hollandiae ac Brabantiae regions' (the regions of Holland and Brabant), followed by:

\begin{abstract}
'A hostile man tried to destroy, ruin and deform this beloved vineyard of the Lord by all means. Unfortunately, ample experience has taught how the heresy of Calvin caused disaster to these flowering churches. Yes, the violence and recklessness of the heretics went so far, that the name Catholic seemed forced to be eradicated in these regions and that there was no possibility whatsoever to repair such great losses.' (Knippenberg, 1992, p. 169)
\end{abstract}

The commotion among conservative Protestants - which became known as the April-movement - was vehement. They did not shun verbal violence. From the pulpit, orthodox ministers compared Roman Catholics with 'Sodom and Gomorrah', 'Egyptian sorcerers' and 'accomplices of Satan'. They wanted to liberate King Willem III and his house 'from the screeching claws of Rome's all-embracing power' (Broere, 1853, cited in van Dijk, 1979, p. 79).

'The old thunder-god Thor' (Thorbecke) was the great wrongdoer. He was seen as the person who wanted to undermine the Protestant Church and overthrow the monarchy. Protestant members of parliament asked the government to protest to the Vatican. The Utrecht Reformed church community started a petition, that had to persuade King Willem III not to approve the restoration of the episcopal hierarchy.

In less than two weeks two hundred thousand people signed the petition, which was a considerable number compared to the electorate, that counted around 80,000 people. This fast success was among other things due to many Protestant ministers, who had supported the petition from the pulpit. However, King Willem III let know that he was bounded by the Constitution, which he had not 
wanted, but that was approved by his father King Willem II. So, he had not the power - in his opinion unfortunately - to meet the wishes of the subscribers of the petition. Besides, this constitutionally less loyal attitude caused a conflict with the Thorbecke-cabinet, that fell at the 19th of April 1853.

This result shows that this was not only a conflict between Protestants and Catholics, but also a struggle between conservative Protestants, who considered the Netherlands a Protestant nation under a Protestant dynasty, and Liberals (also Protestants) under the leadership of Thorbecke, who strived for a strong separation between Church and State, in which former Protestant privileges would no longer be held and the State would no longer interfere in the organisation of the churches on its territory. In fact, the April-movement was also a protest against the liberal Constitution of 1848, that definitively ended those privileges.

\section{TERRITORIALISATION}

The April-movement can also be seen as a protest against an already existing process of territorialising by the Roman Catholic Church in the Netherlands. In his classic study on human territoriality, the American geographer Robert Sack (1986, p. 19) defined territoriality as a strategy 'to affect, influence or control people, phenomena and relationships, by delimiting control over a geographical area'. He also applied this concept to the development and organisation of the Roman Catholic Church, its visible and physic dimensions in particular. This 'visible' church consists of two kinds of territories: firstly, the holy places, religious houses and church buildings, and secondly the territories that were connected with the administrative structure of the church: parishes, dioceses and archdioceses. Both types are very important for the influencing and controlling of believers. The holy places and buildings represent the church in the landscape and in daily life, and are the meeting places for the church communities, where regular religious services are taking place, and religious and personal heydays are being celebrated. The parishes and dioceses demarcate the authority and competences of the church. Every believer knows to which priest he or she belongs, and every priest knows which area he must take care of or must convert. This territorial structure is of eminent importance for the functioning of the church. Therefore Rome was very eager to introducing that structure in the Netherlands (again).

During the first half of the 19th century, the Catholic Church in the Netherlands had become already more visible. New Catholic buildings appeared: churches, chapels, monasteries, schools, rectories, and cemeteries. The increasing presence in the public space of Catholic fraternities with their devotional activities, the processes with all their pomp and circumstance, the Catholic bell-ringing, that all 'stained' the 'Protestant landscape' and gave rise to protests of Protestants, who foresaw a territorial expansion of the Roman church, which had only one goal: bringing back the (Protestant) heretics into the mother church. In their view, the restoration of the episcopal hierarchy was only a next step in this process.

\section{UTRECHT}

Most Catholics were also aware of the importance of this final stage of the restoration, although many local priests in the region of the former Hollandse Zending had problems with the loss of their relatively great autonomy. The territorial episcopal structure could contribute to the unity and wellbeing of the Dutch Catholics, could promote the conversion of Protestants, and could also deliver a sensitive blow to the Oud-Bisschoppelijke Cleresie, a kind of national-Catholic church, that did not recognise the authority of the Pope and existed since the schism of 1723. However, the size of this church was limited. According to the 1849 Census, there were only 5668 so-called Old-Catholics in the Netherlands, $0.2 \%$ of the population, whereas the same Census counted almost 1,2 million Roman Catholics, $38 \%$ of the population.

The seat of the archbishop, who became the head of the Dutch church province, functioned as an important symbol (de Valk, 2002). Rome choose deliberately for the city of Utrecht instead of Den Bosch, which would have been more obvious, since it was located in the Catholic South of the country 
(see Map 1). In this way an offensive strategy was chosen, which was against the advice of the Dutch government and even of Joannes Zwijsen, who in 1853 became the first archbishop. Utrecht was located in the heart of the (predominantly Protestant) Dutch state. In this city, in 1579 the Union of Utrecht was concluded, which marked the beginning of what later became the (Calvinist) Dutch Republic of the United Provinces (1648-1795). Utrecht also hosted the seat of the archbishop of the Oud-Bisschoppelijke Cleresie, which for more than a century had been a thorn in the side of the Roman Curie and was described as 'monstrum ac pestis' in the Papal breve of 1853.

With this choice for Utrecht, Rome not only wanted to stop the Protestant expansion, but also to restore the bond with the pre-Protestant past: from Willibrord and Bonifacius (the first missionaries and bishops in this region) onwards to the 1559 Concordat with the Spanish King Philips II, which also included an archdiocese of Utrecht (that covered more or less the whole part of the Netherlands north of the great rivers).

Consequently, the choice for Utrecht was very important for the integration of the Dutch Catholics in the national community. Den Bosch would have supported the image of the Netherlands as a Protestant nation with a Catholic appendix (Brabant and Limburg), and would have contributed to a territorial solution of the religious diversity. Unintendedly, the Papal choice for Utrecht contributed to the later on development of the non-territorial, personalistic solution for the Dutch multicultural society: the verzuiling. Not a regional, but a national oriented church stood in the minds of Rome and many Catholics, who were living north of the great rivers. So, a national oriented organisational infrastructure was created, which would constitute the skeleton of the Catholic pillar, that would separate itself from the other segments of Dutch society, but at the same time stimulated the integration of Catholics into the Dutch nation and ended their lagging behind in most sectors of Dutch society (see for instance Mandemakers $(1996,274-280)$ concerning the participation in secondary education). This state of affairs continued until the 1960s. Then the pillars crumbled and the contours of a new cultural plurality became visible.

\section{REFERENCES}

Broere, C. (1853). Een bezadigd woord aan mijn welgezinde Protestantsche landgenooten. 's-Gravenhage: Gebr. H. \& H. van Langenhuysen.

de Valk, H. (2002). Meer dan een plaats. De keuze van Utrecht als aartsbisdom in 1853. In J. Vis \& W. Janse (Eds.), Staf en storm. Het herstel van de bisschoppelijke hiërarchie in Nederland in 1853: Actie en reactie (pp. 37-63). Hilversum: Verloren.

Knippenberg, H. (1992). De religieuze kaart van Nederland. Omvang en geografische spreiding van de godsdienstige gezindten vanaf de Reformatie tot heden. Assen: Van Gorcum.

Knippenberg, H. (1999). National integration and growing ethnicity among Dutch Roman Catholics and Protestants in the nineteenth and early twentieth century. The impact of education. Netherlands Journal of Social Sciences, 35(1), 37-52.

Kossmann, E. H. (1976). De lage landen 1780-1940. Anderhalve eeuw Nederland en België. Amsterdam/Brussel: Elsevier.

Lijphart, A. (1975). The politics of accommodation: Pluralism and democracy in the Netherlands (2nd edition). Berkeley: University of California Press.

Mandemakers, C. A. (1996). Gymnasiaal en middelbaar onderwijs. Ontwikkeling, structuur, sociale achtergrond en schoolprestaties, Nederland, ca 1800-1968 (Doctoral dissertation, Erasmus University Rotterdam).

Rogier, L. J. (1956). Katholieke herleving. Geschiedenis van Katholiek Nederland sinds 1853. 's-Gravenhage: Pax.

Sack, R. D. (1986). Human territoriality. Its theory and history. Cambridge: Cambridge University Press.

van Dijk, C. (1979). Hoofdstuk 3. In E. de Jongh \& T. van Tijn (Eds.), 58 Miljoen Nederlanders en hun kerken (pp. 64-91). Utrecht/Antwerpen: Het Spectrum.

Vis, J., \& Janse, W. (Eds.). (2002). Staf en storm. Het herstel van de bisschoppelijke hiërarchie in Nederland in 1853: Actie en reactie. Hilversum: Verloren. 